\title{
Investigation of the Impact of the Guangzhou-Lechang Expressway Segment at the Pajiang River Detention Basin to Its Normal Flood Prevention Operation
}

\author{
Liao Xiao-long*, Wang Xian-ping, Xue Jiao, Yin Kai-Xia, Zhong Yi-Xuan \\ China Water Resources Pearl River Planning, Surveying \& Designing Co. Ltd.
}

\begin{abstract}
Based on the existing relevant information, the paper investigates the occupation situation of the segment of the Guangzhou-Lechang expressway in the Pajiang River detention basin and analyzes the relationship of the water conservancy facility construction to the planning of the detention basin. Onedimensional and two-dimensional mathematical models are established to evaluate the construction effect on flood control in the detention basin under the normal use condition of the Pajiang River. The results show that the construction occupies $0.09 \%$ regulation and storage volume of the detention basin, which leads to the following impacts to its flood prevention operation: the starting time of the detention basin delayed $3 \sim 12$ minutes, the average discharge of the Jiangkouxun section in the main river of the Beijiang River increased $12 \mathrm{~m}^{3} / \mathrm{s}$, and the average discharges of the Tiechuang-ao section of the Pajiang River and the Changbu section of the Yuantan River in the detention basin decreased $14 \mathrm{~m}^{3} / \mathrm{s}$ and $13 \mathrm{~m}^{3} / \mathrm{s}$, respectively. Meanwhile, the highest water level of the Jiangkouxu Station and the peak discharge of the Shijiao Station remain almost the same. Therefore, as the conclusion, the engineering construction of the expressway segment only produces a minor impact on flood control of the Beijiang River. This investigation provides the technical basis for evaluation of the impact to flood prevention by highway construction for similar projects and will be useful for decision-making of the relevant planning agencies.
\end{abstract}

\section{Overview}

\subsection{Overview of the Guangzhou-Lechang Expressway at the Pajiang River Detention Basin}

The Guangzhou-Lechang Expressway (hereinafter referred to as GuangLe Expressway) starts from Xiaotang Town of Lechang City in the north and ends at Huashan Town of Huadu District of Guangzhou City in the south. After crossing the Beijiang River through the North River Bridge in the Jiangkouxun section, the Guangle Expressway crosses the Tiechuang-ao section of the Pajiang River into the detention basin, passing through Xinwei Village, Overseas Chinese Farm, Guoyuan embankment of the detention basin along the west bank of the Yuantan River in a southeastern direction, crossing the Yuantan River and the Beijing-Guangzhou Railway near the Tantang Village, and then leaving the detention basin.
The length of the route through the detention basin is about 4357 meters. Along the route, there are four bridges (Jiuwei Village Bridge, Yinying Separated Interchange Bridge, Guoyuanwei Bridge, and Yuantan River Bridge) with a total bridge length of 2219 meters and roadbed length of 2138 meters ${ }^{[1]}$. The elevation range of the highway and bridge surface is $25.4 \sim 32.6$ meters, which is 3.8 11 meters higher than the 300-year design water level of the starting condition in Pajiang River Detention Basin [2]. The location of the project is shown in Figure 1.

The highways in the eastern concave section of the Xinwei Village and the Overseas Chinese Farm adopt filling roadbed, and the elevation range of the highway surface is $26.20 \sim 30.88$ meters, which is 3.8 11 meters higher than the 300-year design water level. The roadbeds in the two positions are equipped with drainage (inlet) culvert and traffic culvert. The cross-sectional size of both drainage culverts is $6 \mathrm{~m} \times 5 \mathrm{~m}$, and the cross-sectional size of both traffic culverts is $6 \mathrm{~m} \times 4 \mathrm{~m}$ and $4 \mathrm{~m} \times 3 \mathrm{~m}$ respectively.

Table 1. The characteristic parameter of bridge construction

\begin{tabular}{|c|c|c|c|c|}
\hline Bridge & Length $(\mathrm{m})$ & Surface Elevation $(\mathrm{m})$ & Bottom Elevation $(\mathrm{m})$ & Diameter of Pier $(\mathrm{m})$ \\
\hline Jiuwei Village Bridge & 486 & $26.93 \sim 32.18$ & $26.67 \sim 31.93$ & 1.3 \\
\hline Yinying Separated Interchange Bridge & 380 & $31.75 \sim 33.35$ & $28.95 \sim 31.50$ & $1.3 \sim 2.5$ \\
\hline Guoyuanwei Bridge & 660 & $24.78 \sim 26.46$ & $23.48 \sim 25.16$ & 1.3 \\
\hline
\end{tabular}

\footnotetext{
*Corresponding author: 178462035@qq.com
} 


\begin{tabular}{|l|l|l|l|l|} 
Yuantan River Bridge & 693 & $26.14 \sim 33.42$ & $25.68 \sim 31.81$ & $1.4 \sim 3.0$ \\
\hline
\end{tabular}

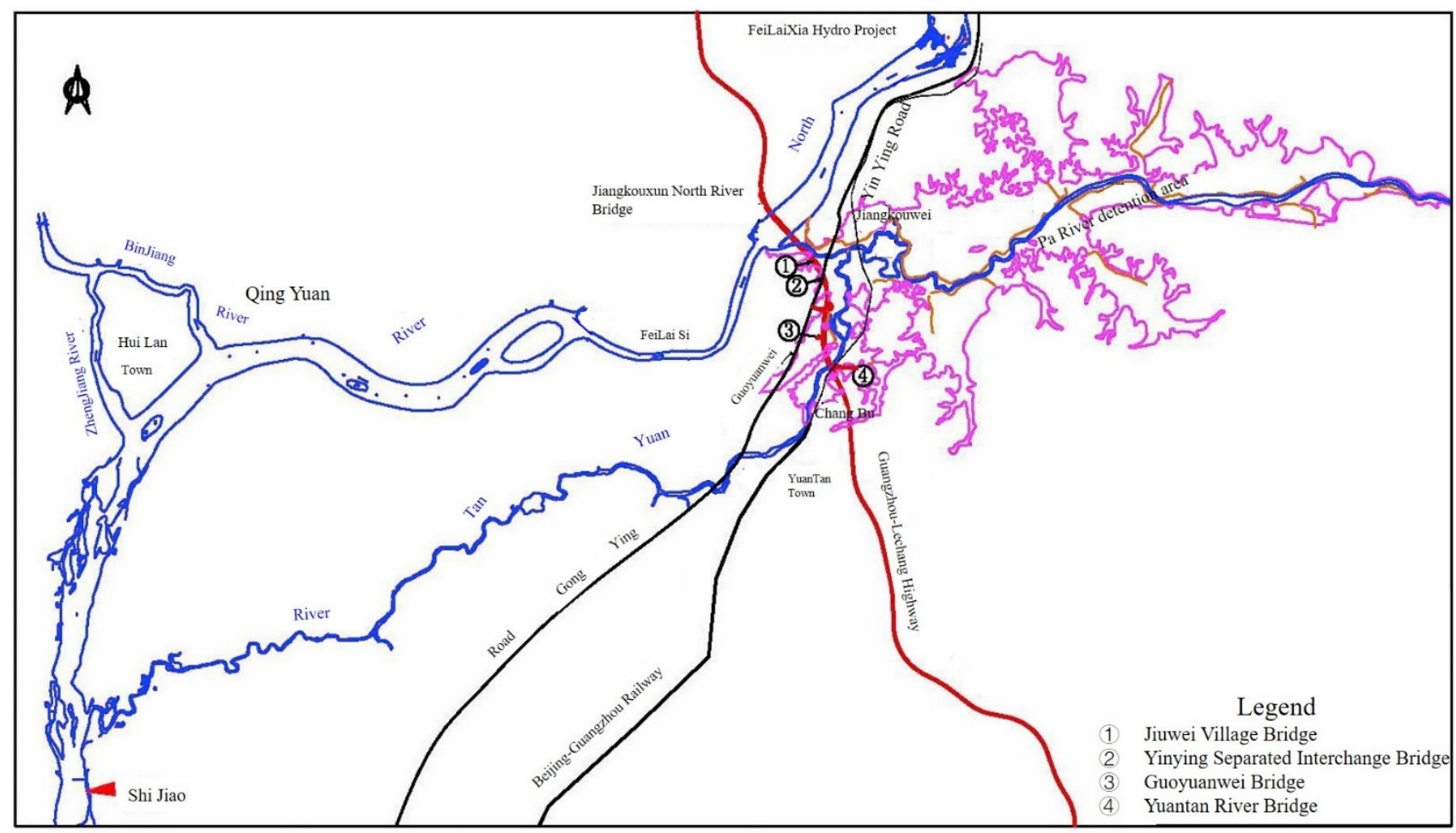

Fig. 1. Map of the geographic position of the Pajiang River Detention Basin

\subsection{Overview of Pajiang River Detention Basin}

Pajiang River Detention Basin is located some $10 \mathrm{~km}$ downstream of the left bank of The Feilaixia Hydro Project, with low-lying terrain and a general surface elevation of 12 15 meters. The total area below a 22.0meter elevation of the detention basin of the river is 79.80 $\mathrm{km}^{2}$, with a corresponding total reservoir capacity of 411 million $\mathrm{m}^{3}$. Pajiang River Detention Basin is a natural flood plain in the lower reaches of the Beijiang River, which can divert and detent floodwater in the Beijiang River. In the Flood Control Planning of the Pearl River Basin approved by the State Council in 2007, Pajiang River Detention Basin has been clearly defined as part of the flood control engineering system of the Beijiang River.

A natural flood control scheme ${ }^{[3]}$ is adopted in Pajiang River Detention Basin for flood diversion. When the flood comes, the floodwater in the Beijiang River naturally backflows into the detention basin and then is stored in the natural flood plain outside the embankment. When the water level of the Jiangkouxu Station in the basin exceeds 19.0 meters, the Dushu embankment and the Shubotang embankment are activated to control the flood. When the water level of the Jiangkouxu Station exceeds 20.8 meters, all the embankments in the basin will be broken down and the detention basin starts to control the flood across-theboard.

\section{Occupation Situation in the Detention Basin}

\subsection{Occupation of Flood Diversion (Discharge) Channels}

The main flood diversion (discharge) channels of Pajiang River Detention Basin are the mouth of the Pajiang River and the Yuantan River. The North River Bridge at Jiangkouxun crosses the mouth of the Pajiang River, and the Yuantan River Bridge crosses over the Yuantan River in Tantang Village, and the bridge pier occupies the flood flowing area of the flood diversion channel of the mouth of the Pajiang River and the flood discharge channel of the Yuantan River. Under the 300-year flood condition, the water-blocking ratio of the North River Bridge in the Jiangkouxun section occupying the flood diversion channel of the mouth of the Pajiang River is $6.72 \% \sim 6.92 \%$, and the water-blocking ratio of the Yuantan River Bridge occupying the flood discharge channel of the Yuantan River is 5.92\% 6.02\%.

\subsection{Occupation of the Storage volume in the Detention Basin}

The length of the Guangle Expressway within Pajiang River Detention Basin is about $4.4 \mathrm{~km}$, and the project may affect the flood storage volume of the Pajiang River in the downstream concave section of the Datangwei Reservoir, the eastern concave section of the Xinwei Village, and the 
Guoyuan embankment. About 13.61 million $\mathrm{m}^{3}$ storage volume in the detention basin will be affected, accounting for $3.31 \%$ of the total occupied volume in the detention basin. The flood storage volume of the Guoyuan embankment is the largest, which is 9.75 million $\mathrm{m}^{3}$. In this project, Jiuwei Village Bridge, Guoyuanwei Bridge, Yinying Separated Interchange Bridge, and water inlet culverts are constructed to ensure smooth flood diversion and detention in these areas.

The road (bridge) foundation construction permanently occupies a volume of $380,000 \mathrm{~m}^{3}$ in the detention basin, which is about $0.09 \%$ of the storage volume in the detention basin. The occupied percents of area and volume in the detention basin are shown in Table 2.

Table 2. The occupied percent of area and volume in detention basin

\begin{tabular}{|c|c|c|c|c|c|}
\hline \multirow[b]{2}{*}{ Location } & \multicolumn{2}{|c|}{ Area } & \multicolumn{2}{|c|}{ Volume } & \multirow[b]{2}{*}{ Remarks } \\
\hline & $\begin{array}{c}\text { Area } \\
\left(\mathrm{km}^{2}\right)\end{array}$ & $\begin{array}{l}\text { Occupied } \\
\text { Percent in } \\
\text { Detention } \\
\text { Basin (\%) }\end{array}$ & $\begin{array}{l}\text { Volume } \\
\text { (million } \\
\mathrm{m}^{3} \text { ) }\end{array}$ & $\begin{array}{l}\text { Occupied } \\
\text { Percent in } \\
\text { Detention } \\
\text { Basin }(\%)\end{array}$ & \\
\hline Roadbed & 0.064 & 0.08 & 0.38 & 0.09 & Permanently occupied \\
\hline Datangwei & 0.198 & 0.25 & 1.58 & 0.38 & \multirow{4}{*}{$\begin{array}{l}\text { Flood water can enter } \\
\text { these areas through } \\
\text { apertures and culverts } \\
\text { of the bridges. }\end{array}$} \\
\hline $\begin{array}{c}\text { Yinying } \\
\text { Interchange Bridge } \\
\text { section in Xinwei } \\
\text { Village }\end{array}$ & 0.068 & 0.09 & 0.54 & 0.13 & \\
\hline $\begin{array}{l}\text { Yinfu Brick Field } \\
\text { section in Xinwei } \\
\text { Village }\end{array}$ & 0.170 & 0.21 & 1.36 & 0.33 & \\
\hline $\begin{array}{c}\text { Guoyuan } \\
\text { embankment }\end{array}$ & 1.735 & 2.17 & 9.75 & 2.37 & \\
\hline Total & 2.234 & 2.80 & 13.61 & 3.31 & \\
\hline
\end{tabular}

\section{Relationship with the Water Conservancy Facility Construction and Related Planning of the Pajiang River Detention Basin}

\subsection{Relationship with the Existing Embankments in the Pajiang River Detention Basin}

Currently, there are 17 embankments in Pajiang River Detention Basin, with a total length of $55.45 \mathrm{~km}$. Most of the embankments were built in the 20th century, but in recent years, many of them have been repaired and reinforced so that their flood control capacity has been improved, and their flood control standard is a 10 -year to 20-year flood.

The embankments in Pajiang River Detention Basin are mainly located to the east of the Yuantan River and are far from the Guangle Expressway. The embankments to the west of the Yuantan River are Guoyuan embankment and Tianji embankment. Tianji embankment is located $1.5 \mathrm{~km}$ downstream of the Yuantan River Bridge in the Guangle Expressway, which is almost not affected by the Guangle Expressway. The embankment closest to the Guangle Expressway is Guoyuan embankment. Both the entity roadbed section of the Overseas Chinese Farm and the Guoyuanwei Bridge is located within Guoyuan embankment. The entity roadbed section of the Overseas Chinese Farm is 60 70 meters away from the foot of the Guoyuan embankment, and the Guoyuanwei Bridge is 150 350 meters away from the foot of the Guoyuan embankment, so the safety of the Guoyuan embankment is basically not affected.

\subsection{Relationship with the Safety Construction Planning Project in the Detention Basin}

Currently, Pajiang River Detention Basin is a natural flood detention area. According to the Construction and Management Planning Report in the Detention Basin of the Pearl River, the safety construction projects in Pajiang River Detention Basin include one safety zone, 23 resettlement areas, $29.42 \mathrm{~km}$ of new retreat roads, $70 \mathrm{~km}$ of existing road renovation, two new retreat bridge culverts, 5000 temporary resettlement tents, and two sets of communication and early warning systems.

\subsubsection{Relationship with the Safety Zone}

The safety zone is located in the Jiangkouxu protection zone. The Guangle Expressway does not pass through the safety zone. An interchange ramp connecting the Yinying Highway is built on the west slope of the Overseas Chinese Farm on the Guangle Expressway. Personnel and vehicles in the safety zone can retreat through the Jiangkouxu to Xinwei Village section of rural roads and the Yinying Highway into the Guangle Expressway. Also, 
disaster relief supplies can be quickly transported to the safety zone through the Guangle Expressway.

\subsubsection{Relationship with Resettlement Areas}

Resettlement areas are mainly located in the eastern area of the Yuantan River. The Guangle Expressway does not pass through the resettlement areas, and the resettlement area closest to the Guangle Expressway is the resettlement area behind the Xinwei Village. Since the Guangle Expressway uses a bridge to cross the downstream lowlying area of the Datangwei and the Yinying Highway, the evacuees near the Xinwei Village can cross the Guangle Expressway under the bridge and enter the resettlement area behind. Therefore, the Guangle Expressway does not affect the backward resettlement of evacuees.

\subsubsection{Relationship with Roads}

Traffic culverts are set at the crossings of the current rural roads and the Guangle Expressway, and the dimensions of the traffic culverts meet the requirements of rural roads. The planned roads in the detention basin of the river are located in the Yinsha Village to Dushu Village section and the Xiale Road to Dahailiao section in Jiangkouxu, and the Guangle Expressway does not intersect with the planned roads. In addition, the Guangle Expressway has set up interchange ramps of the Overseas Chinese Farm to connect with the Yinying Highway and roads in the detention basin. Therefore, the proposed project does not affect the normal use of the existing and planned roads.

\subsubsection{Relationship with Flood Diversion and Drainage Project}

Except for Guoyuan embankment, the Guangle Expressway does not intersect with any other embankments and will not affect the normal use of flood diversion and drainage projects of other embankments. The Guoyuan embankment uses wrapping to control flood diversion, and the design width of the wrapped area is 10 meters. The Guoyuanwei Bridge of the Guangle Expressway is $33 \mathrm{~m} \times 20 \mathrm{~m}$, the total net width under the bridge is 617 meters, and the beam elevation is 23.48 25.16 meters, which is 4.56 6.24 meters higher than the designed 300-year water level. Therefore, it can be judged qualitatively that the bridge has a small influence on the flood diversion of Guoyuan embankment.

\section{Analysis of the Effect on Flood Control in Detention Basin of Normal Use}

The project in Pajiang River Detention Basin section of the Guangle Expressway is $10 \mathrm{~km}$ away from the upstream The Feilaixia Hydro Project, and $41 \mathrm{~km}$ away from the downstream Shijiao hydrological station, the flood control section of the Beijiang basin. The scope of the project is large and the flow conditions are complex. For the analysis of the effect on flood control in the detention basin of a large scope, the methods currently used include the one-dimensional flow mathematical model ${ }^{[4]}$, the two-dimensional flow mathematical model [5], and the one-dimensional and two-dimensional combined flow mathematical model ${ }^{[6]}$. Drawing on previous research results in this area, this paper adopts the one-dimensional and two-dimensional combined flow mathematical model to study the impact on flood control in the detention basin of normal use in the Pajiang River.

\subsection{Establishment and Validation of the One- Dimensional and Two-Dimensional Combined Flow Mathematical Model}

\subsubsection{Fundamentals of the Flow Mathematical Model}

The basic equations used in the one-dimensional flow mathematical model are the Saint-Venant equations ${ }^{[7]}$.

$$
\begin{aligned}
& \frac{\partial A}{\partial t}+\frac{\partial Q}{\partial s}=q+\delta Q_{c} \\
& \frac{\partial Q}{\partial t}+\frac{\partial\left(Q^{2} / A\right)}{\partial s}=-g A \frac{\partial z}{\partial s}-g A \frac{Q^{2}}{K^{2}}
\end{aligned}
$$

Where $A$ is the area of the flow cross-section of the channel, $\mathrm{Q}$ is the cross-sectional flow, $\mathrm{q}$ is the uniform lateral inflow, $Q_{c}$ is the concentrated lateral inflow, $\mathrm{z}$ is the water level, and $\mathrm{K}$ is the modulus of flow calculated by the Chézy formula.

The two-dimensional mathematical model uses an orthogonal body-fitted coordinate system, and the continuity equation and the movement equation of flows are used. The fundamental equations are as follows ${ }^{[8]}$.

$$
\begin{gathered}
\frac{\partial h}{\partial}+\frac{1}{C_{\xi} C_{\eta}}\left[\frac{\partial\left(C_{\eta} H u\right)}{\partial \xi}+\frac{\partial\left(C_{\xi} H v\right)}{\partial \eta}\right]=0 \\
\frac{\partial(H u)}{\partial t}+\frac{1}{C_{\xi} C_{\eta}}\left[\frac{\partial}{\partial \xi}\left(C_{\eta} H u u\right)+\frac{\partial}{\partial \eta}\left(C_{\xi} H v u\right)+H v u \frac{\partial C_{\xi}}{\partial \eta}-H v^{2} \frac{\partial C_{\eta}}{\partial \xi}\right] \\
=-\frac{g u \sqrt{u^{2}+v^{2}}}{C^{2}}-\frac{g H}{C_{\zeta}} \frac{\partial h}{\partial \xi}+ \\
\frac{1}{C_{\xi} C_{\eta}}\left[\frac{\partial}{\partial \xi}\left(C_{\eta} H \sigma_{\xi \eta}\right)+\frac{\partial}{\partial \eta}\left(C_{\xi} H \sigma_{\xi \xi}\right)+H \sigma_{\xi \eta} \frac{\partial C_{\xi}}{\partial \eta}-H \sigma_{\eta \eta} \frac{\partial C_{\eta}}{\partial \xi}\right] \\
\frac{\partial(H v)}{\partial t}+\frac{1}{C_{\xi} C_{\eta}}\left[\frac{\partial}{\partial \xi}\left(C_{\eta} H u v\right)+\frac{\partial}{\partial \eta}\left(C_{\xi} H v v\right)+H u v \frac{\partial C_{\xi}}{\partial \eta}-H u^{2} \frac{\partial C_{\eta}}{\partial \xi}\right] \\
=-\frac{g v \sqrt{u^{2}+v^{2}}}{C^{2}}-\frac{g H}{C_{\eta}} \frac{\partial h}{\partial \eta}+ \\
\frac{1}{C_{\xi} C_{\eta}}\left[\frac{\partial}{\partial \xi}\left(C_{\eta} H \sigma_{\xi \eta}\right)+\frac{\partial}{\partial \eta}\left(C_{\xi} H \sigma_{\eta \eta}\right)+H \sigma_{\xi \eta} \frac{\partial C_{\xi}}{\partial \eta}-H \sigma_{\xi \xi} \frac{\partial C_{\eta}}{\partial \xi}\right]
\end{gathered}
$$

In the above equations, $\mathrm{h}$ is the water level, $\mathrm{H}$ is the water depth, $\mathrm{u}$ and $\mathrm{v}$ are the flow velocity components in the direction of $\xi$ and $\eta, C_{\xi}$ and $C_{\eta}$ are the Lame coefficients of the orthogonal curvilinear coordinate 
system, $\sigma_{\xi \xi}, \sigma_{\eta \eta}, \sigma_{\xi \eta}$, and $\sigma_{\eta \xi}$ are the stresses on the vertical plane, and $v_{t}$ are the rate coefficient of kinematic viscosity.

The controlling equations in the one-dimensional model are solved by the Preissmann finite-difference scheme in terms of discretization and the "Three-Steps Method" of the river network ${ }^{[9-10]}$, while the controlling equations in the two-dimensional model are solved by the finite-volume method in terms of discretization and the SIMPLEC algorithm for water depth correction ${ }^{[11]}$. The one-dimensional and two-dimensional models are combined by means of the "semi-coupling" technique ${ }^{[8]}$. The one-dimensional outlet is fixed as the water level boundary, and the one-dimensional calculation results provide the flow boundary conditions for the twodimensional calculation. The two-dimensional inlet is fixed as the flow boundary, and the two-dimensional calculation results provide the water level boundary conditions for the one-dimensional calculation.

\subsubsection{Model Calculation Range and Topographic Information}

\subsubsection{Model Range}

The upper boundaries of the two-dimensional flow mathematical model are The Feilaixia of the Beijiang River and Zhanguo Village of the Pajiang River. The lower boundaries are Lijiazhuang of the Beijiang River and Dailingtou of Yuantan River, which lies at lower reaches of Changbu.

The upper boundaries of the one-dimensional flow mathematical model are connected to the lower boundaries of the two-dimensional model, and the lower boundary is Shijiao hydrological station of Beijiang River, the discharge of Pajiang River and Binjiang River are treated as the local inflow.

\subsubsection{Topographic Information Used in the Model}

For the topographic information of the two-dimensional model, the 1/5000 channel map measured by the survey team of Guangdong Channel Survey and Design Institute in 2001 was used for the main river of the Beijiang River, and the 1:10,000 topographic map measured by the Department of Land and Resources in 1999 was used for the detention basin of the Jiujiang River.

For the topographic information of the onedimensional model, the 1/5000 channel map measured by the survey team of Guangdong Channel Survey and Design Institute in 2001 was used for the main river of the Beijiang River. As for the topographic information of the Pajiang River and Binjiang River, the 1/5000 crosssectional measurement results of our company in 2004 was adopted.

\subsubsection{Model Validation}

This paper uses the "1994.06" flood to investigate the water level in the detention basin of the river for model calibration. The calibration results are shown in Table 3. From the error of the calculated water level and the investigated water level, in addition to Baishatang embankment where the calculated water level is relatively higher than the investigated water level, other validation sites have a small error in terms of the calculated water level, indicating that the calculation parameters selected in the one-dimensional and two-dimensional models are reasonable and can be used for analyzing the numerical simulation of the impact on flood control of the project.

Table 3. Object list of the modeling verification using "1994.06" flood

\begin{tabular}{|c|c|c|c|c|c|c|c|}
\hline $\begin{array}{c}\text { Validation } \\
\text { Sites }\end{array}$ & $\begin{array}{c}\text { Investigated } \\
\text { Water Level }\end{array}$ & $\begin{array}{c}\text { Calculated } \\
\text { Water } \\
\text { Level }\end{array}$ & Error & $\begin{array}{c}\text { Validation } \\
\text { Sites }\end{array}$ & $\begin{array}{c}\text { Investigated } \\
\text { Water Level }\end{array}$ & $\begin{array}{c}\text { Calculated } \\
\text { Water Level }\end{array}$ & Error \\
\hline $\begin{array}{c}\text { Fandian } \\
\text { embankme } \\
\mathrm{nt}\end{array}$ & 21.94 & 21.95 & 0.01 & $\begin{array}{c}\text { Guoyuan } \\
\text { embankme } \\
\mathrm{nt}\end{array}$ & 20.60 & 20.63 & 0.03 \\
\hline $\begin{array}{c}\text { Dachang } \\
\text { embankme } \\
\mathrm{nt}\end{array}$ & 21.67 & 21.67 & 0.00 & $\begin{array}{c}\text { Gaoqiao } \\
\text { embankme } \\
\mathrm{nt}\end{array}$ & 21.57 & 21.56 & -0.01 \\
\hline $\begin{array}{c}\text { Dushu } \\
\text { embankme } \\
\mathrm{nt}\end{array}$ & 21.84 & 21.82 & -0.02 & $\begin{array}{c}\text { Xiayue } \\
\text { embankme } \\
\mathrm{nt}\end{array}$ & 22.11 & 22.08 & -0.03 \\
\hline $\begin{array}{c}\text { Changbu } \\
\text { embankme } \\
\mathrm{nt}\end{array}$ & 20.30 & 20.32 & 0.02 & $\begin{array}{c}\text { Baishatang } \\
\text { embankme } \\
\mathrm{nt}\end{array}$ & 21.75 & 21.79 & 0.08 \\
\hline
\end{tabular}




\subsection{Analysis of the Effect on the Operation of the Pajiang River Detention Basin}

Based on the above-mentioned flow mathematical model with the one-dimensional and two-dimensional models combined, we analyze the effect of the project on the regulation and storage operation of the detention basin in the river in face of a 300-year flood of the Beijiang River as the "1968.06" flood. The impacts of the project on the starting time of flood diversion in Pajiang River Detention Basin, the average discharge and maximum diversion discharge at the controlling section, and the highest water level in Pajiang River Detention Basin are shown in Table 4. The variation in the water level of Jiangkouxu before and after the project was completed in the control station of Pajiang River Detention Basin is shown in Figure 2. The variation in the discharge of the Shijiao hydrological station before and after the project was completed in the flood control section of the Beijiang River is shown in Figure 3. According to the analysis of the calculation results, the characteristics of the operation variation in the detention basin after the project completed are concluded as follows:

1) For the 300-year flood after the regulation of the Feilaixia, the flood diversion starting time of the embankments, which were partially broken down, in Pajiang River Detention Basin was delayed by three minutes, while that of the embankments, which were fully broken down, was delayed by 12 minutes.

2) After the construction of the highways, the average discharge of the Jiangkouxun section in the main river of the Beijiang River increased by $12 \mathrm{~m}^{3} / \mathrm{s}$, accounting for an increase of $0.11 \%$. The average discharge of the Tiechuangao section of the Pajiang River decreased by 14 $\mathrm{m}^{3} / \mathrm{s}$, accounting for a reduction of $0.49 \%$. The average discharge of the Changbu section of the Yuantan River decreased by $13 \mathrm{~m}^{3} / \mathrm{s}$, accounting for a reduction of $0.42 \%$. The peak discharge of the Shijiao Station remained almost unchanged.

3) According to the analysis of the water level variation process and the highest water level before and after the project at the Jiangkouxu Station completed, the discharge of the main river of the Beijiang River into Pajiang River Detention Basin after the project completed was slightly reduced, and the time of flood diversion was slightly delayed, which led to the highest water level increase of 0.2 meters at the Jiangkouxu Station during the time of embankment breakdown (1.5h) compared with that before the project. In other times, since the maximum flow of the Pajiang River encountered by the tributaries of the river was smaller than that before the project, the water level of the Jiangkouxu Station after the project would slightly decrease. Besides, the highest water level of the Jiangkouxu Station was also lower than that before the project, and the reduction is within 0.01 meters.

4) The proposed highway crossed through the Guoyuan embankment using an elevated bridge. The bridge had a hole span of $30 \times 20+3 \times 20$ meters, the diameter of pier of 1.3 meters, the total net width of the bridge hole up to 617 meters, which was 607 meters wider than that of the designed wrapping in the Guoyuan embankment. In addition to that, a $6 \mathrm{~m} \times 5 \mathrm{~m}$ drainage culvert was designed on the concave area of the Overseas Chinese Farm. Through the mathematical model calculation analysis, it was found that the proposed bridge did not affect the flood division of the Guoyuan embankment.

5) The proposed bridge was arranged with a $6 \mathrm{~m} \times 5 \mathrm{~m}$ (width $\times$ height, the same below) drainage culvert in the entity roadbed section of the Xinwei Village. The area within the entity roadbed section of the Xinwei Village was $0.170 \mathrm{~km}^{2}$, and the volume below 22 meters was 1.36 million $\mathrm{m}^{3}$, accounting for $0.33 \%$ of the total volume of Pajiang River Detention Basin. The calculation results show that the drainage culvert can generally meet the requirement of getting the flood water into the low-lying areas within the entity roadbed for flood detention.

6) From the analysis of the water level variation process of the Jiangkouxu Station and the discharge variation process of the Shijiao hydrological station, except for the breakdown time of the Pajiang River when the water level and discharge of the two stations are different, the water level of the Jiangkouxu Station and the discharge of the Shijiao hydrological station are not very different in other times. Therefore, the proposed project has less impact on the flood recession of the detention basin in the Pajiang River.

In summary, the proposed highway has little effect on the starting time, flood diversion effect, and flood recession process of Pajiang River Detention Basin, and does not affect the peak discharge of the Shijiao Station, which is the flood control station in the Beijiang River.

Table 4. Object list of the effects of the expressway on flood control in detention basin of normal use

\begin{tabular}{|c|c|c|c|c|}
\hline \multicolumn{2}{|c|}{ Project } & $\begin{array}{l}\text { Befo } \\
\text { re } \\
\text { the } \\
\text { Proje } \\
\text { ct }\end{array}$ & $\begin{array}{l}\text { Afte } \\
\mathrm{r} \text { the } \\
\text { Proj } \\
\text { ect }\end{array}$ & $\begin{array}{l}\text { Vari } \\
\text { atio } \\
n \\
\text { Valu } \\
\text { e }\end{array}$ \\
\hline \multirow{2}{*}{$\begin{array}{c}\text { Flood } \\
\text { Diversion } \\
\text { Time of } \\
\text { Broken } \\
\text { Embankments }\end{array}$} & Partially Broken & $\begin{array}{l}6-23 \\
9: 44 \\
\end{array}$ & $\begin{array}{l}6-23 \\
9: 47 \\
\end{array}$ & $\begin{array}{c}3 \mathrm{mi} \\
\mathrm{n}\end{array}$ \\
\hline & Fully Broken & $\begin{array}{l}6-24 \\
4: 28\end{array}$ & $\begin{array}{l}6-24 \\
4: 40\end{array}$ & $\begin{array}{c}12 \mathrm{~m} \\
\text { in }\end{array}$ \\
\hline \multirow{4}{*}{$\begin{array}{l}\text { Average } \\
\text { Discharge } \\
\left(\mathrm{m}^{3} / \mathrm{s}\right)\end{array}$} & $\begin{array}{c}\text { Jiangkouxun } \\
\text { Section in the } \\
\text { Main River of the } \\
\text { Beijiang River }\end{array}$ & $\begin{array}{c}1120 \\
7\end{array}$ & $\begin{array}{c}1121 \\
8\end{array}$ & 12 \\
\hline & $\begin{array}{l}\text { Tiechuangao } \\
\text { section of the } \\
\text { Pajiang River }\end{array}$ & 2875 & 2861 & -14 \\
\hline & $\begin{array}{c}\text { Changbu Section } \\
\text { of the Yuantan } \\
\text { River }\end{array}$ & 3122 & 3109 & -13 \\
\hline & $\begin{array}{c}\text { Shijiao } \\
\text { hydrological } \\
\text { station } \\
\end{array}$ & $\begin{array}{c}1435 \\
6\end{array}$ & $\begin{array}{c}1436 \\
0\end{array}$ & 5 \\
\hline \multirow{2}{*}{$\begin{array}{c}\text { Peak } \\
\text { Discharge } \\
\left(\mathrm{m}^{3} / \mathrm{s}\right)\end{array}$} & $\begin{array}{c}\text { Jiangkouxun } \\
\text { Section in the } \\
\text { Main River of the } \\
\text { Beijiang River }\end{array}$ & $\begin{array}{c}1282 \\
4\end{array}$ & $\begin{array}{c}1282 \\
8\end{array}$ & 5 \\
\hline & $\begin{array}{l}\text { Tiechuangao } \\
\text { section of the } \\
\text { Pajiang River }\end{array}$ & 4688 & 4668 & -20 \\
\hline
\end{tabular}




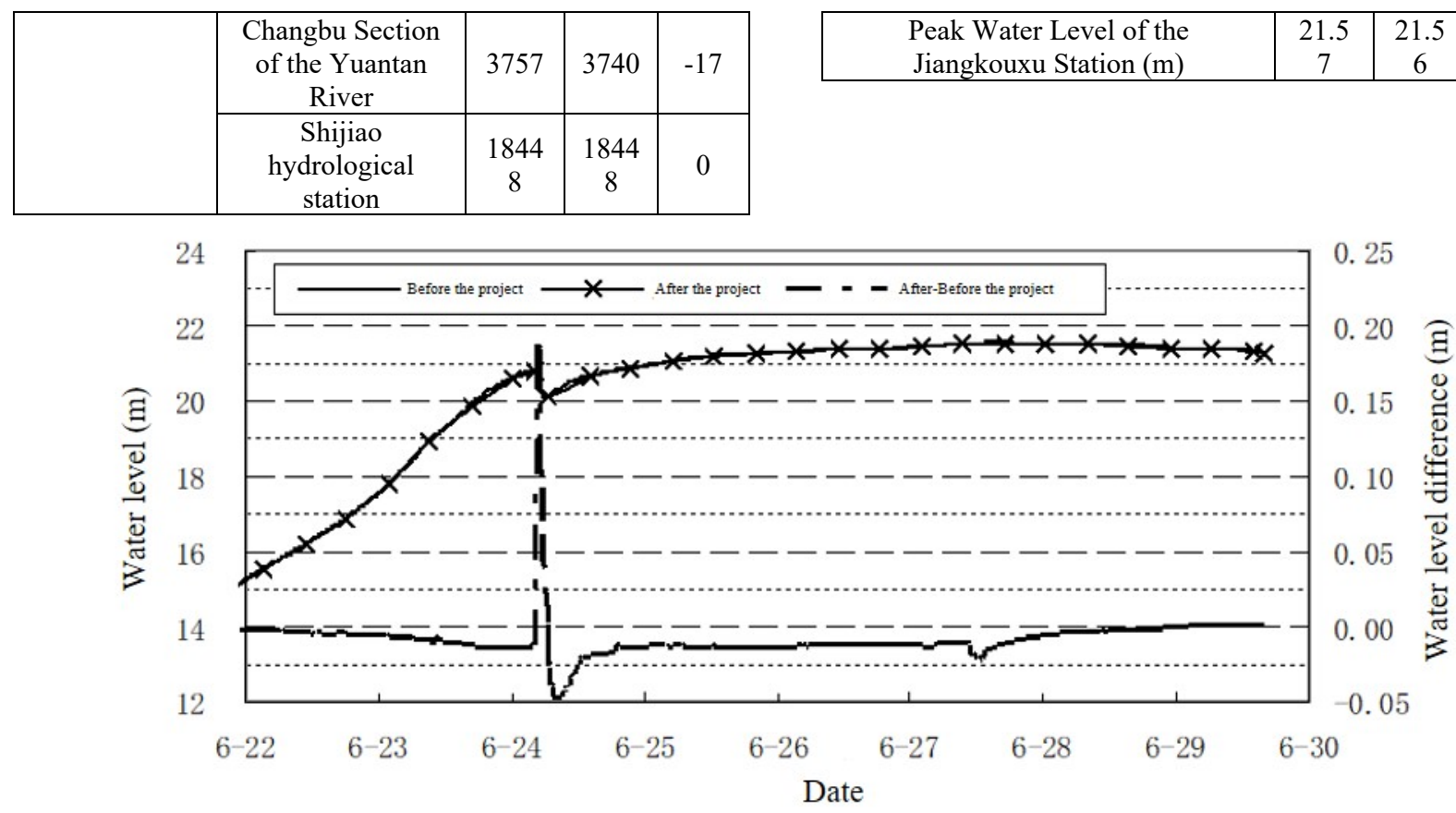

Fig. 2. Variation in water table of Jiangkouxu before and after the project completed

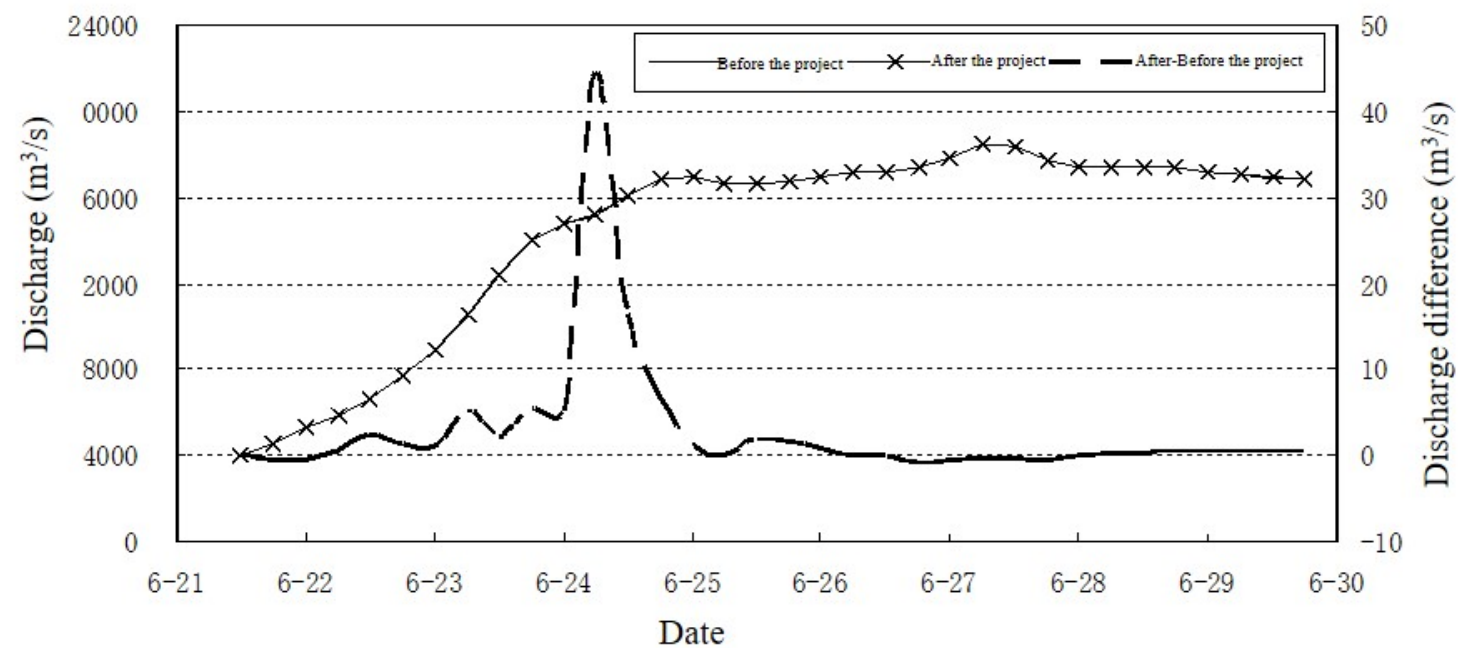

Fig. 3. Variation in discharge of Shijiao hydrological station before and after the project completed

\section{Conclusion}

Based on the above analysis of basic information and the simulation results of the flow mathematical model, the following conclusions can be drawn.

1) Under the condition of a 300-year flood, the waterblocking ratio of the project in the detention basin section of the Pajiang River of the GuangLe Expressway occupying the flood diversion channel at the mouth of the Pajiang River is $6.72 \% \sim 6.92 \%$, and the water-blocking ratio of the project occupying the flood discharge channel of the Yuantan River is $5.92 \% \sim 6.02 \%$.

2) The project in the Pajiang River detention basin of the GuangLe Expressway affects about 13.61 million $\mathrm{m}^{3}$ of the detention basin in the Pajiang River, accounting for $3.31 \%$ of the total volume of the detention basin. Road (bridge) foundation construction permanently occupies about $380,000 \mathrm{~m}^{3}$ of the detention basin, occupying about the $0.09 \%$ volume of the detention basin.

3) The project in the detention basin section of the Pajiang River of the GuangLe Expressway does not occupy the existing and planned embankments and water conservancy engineering facilities in Pajiang River Detention Basin, and it does not affect the implementation of the safety construction planning project of the detention basin.

4) Based on the calculation analysis of the 300-year flood as the "1968.6" flood after the regulation of Feilaixia through the mathematical flow model, the starting time of broken embankments in Pajiang River Detention Basin is delayed from 3 minutes to 12 minutes. The average discharge of the Jiangkouxun section in the main river of the Beijiang River is increased by $12 \mathrm{~m}^{3} / \mathrm{s}$. The average 
discharge of the Tiechuangao section of the Pajiang River is decreased by $14 \mathrm{~m}^{3} / \mathrm{s}$. The average discharge of the Changbu section in the Yuantan River is reduced by 13 $\mathrm{m}^{3} / \mathrm{s}$. The highest water level of the Jiangkouxu Station and the peak flow of the Shijiao Station are almost unchanged. The project has little impact on the use of Pajiang River Detention Basin, which does not have adverse impacts on the flood control of the middle and lower reaches of the Beijiang River in general.

\section{Reference}

1. WANG Jing, WANG Yan-jun, et al. Feasibility Study Report of the Guangzhou to Lechang expressway[R], ChengDu: China Railway Er Yuan Engineering Group CO.LTD, 2008. (In Chinese)

2. WAN Xian-ping, LIAO Xiao-long, et al. Evaluation report about the effects of Guangzhou to Lechang expressway of the segment of the detention basin of the Pajiang River[R], Guangzhou: China Water Resource Pearl River Planning Surveying \& Desingning CO.LTD, 2009. (In Chinese)

3. SUO Xiao-bo, LIAO Xiao-long, et al. Planning report about the construct and management of the detention basin of the Pajiang River[R], Guangzhou: China Water Resource Pearl River Planning Surveying \& d Desingning CO.LTD, 2006. (In Chinese)

4. QIN Lian-chao, YU Ming-hui, LI Er-ming, TAN Guang-ming, Research on numerical simulation of regulation of Dujiatai flood diversion area and effect on flood diversion[J] , Journal of Sediment Research, ,2011(3): 38-43. (In Chinese)

5. LIU Xiao-qun, HAO Zhen-chun, XUE Lian-qing, Xu Chao, the study about flood storage in Dong-ting Lake[J], Yangtze River, 2009(14):80-83. (In Chinese)

6. Qiao Wei, Zhang Xiao-feng, Analysis on the effect of honghu Flood diversion and storage Area on reducing Yangtze River water level[J], Yangtze River, 2009(11):15-17. (In Chinese)

7. XIE Zuo-tao, ZHANG Xiao-feng, YUAN Jing, Numerical simulation of dam-break floods[J], HYDRO-SCIENCE AND ENGINEERING, 2005(2): 9-17. (In Chinese)

8. ZHANG Hua-qing1, JIN Sheng2, et al. Report about Mathematical Model of Flow and Sediment in Pearl River Delta and Estuary[R], Tianjing: Tianjin Research Institute of Water Transport Engineering, 2002. (In Chinese)

9. Math department of Sun Ye-sant University, the Second Report about Unsteady flow calculation in Pearl River Delta[R], Guangzhou: Sun Ye-sant University, 1977. (In Chinese)

10. Zhang Er-jun Zhang Dong-sheng Li Ting, Three Steps Method" to Compute Unsteady Flow for River
Networks[J], Journal of Hohai University (Natural Sciences),1982(1):19-231. (In Chinese)

11. Van Doormaal J P. Raithby G D, Enhancement of SIMPLE method for predicting incompressible fluid flows [ J] , Numer Heat Transfer, 1984 (7):147-163. 